\title{
AMOR AMICITIAEE AMOR CONCUPISCENTIAE: UM ESTUDO SOBRE AS NOÇÕES DE AMOR, DESEJO E AMIZADE NA SUMA DE TEOLOGIA DE TOMÁS DE AQUINO
}

\author{
Antônio A. C. Couto \\ Universidade Estadual de Santa Cruz
}

Resumo: 0 artigo trata da distinção entre amor de amizade, ou de benevolência, e amor de concupiscência na Suma Teológica de Tomás de Aquino. Explicita as relações de semelhança e diferença que a noção de amor mantém com as noções que constituem a distinção, a saber: concupiscência, desejo, amizade e benevolência. Evidencia os fundamentos da teoria do amor de Tomás de Aquino no pensamento de Aristóteles: a concepção física da psicologia que funda a teoria do apetite, a analogia da distinção do amor com a divisão metafísica do ser, as origens éticas dessa distinção na tripla divisão da amizade: útil, agradável e virtuosa. Estuda diferentes usos da distinção do amor em "de amizade" e "de concupiscência", e investiga a pertinência de atribuir, como pretenderam alguns, uma dupla concepção a essa distinção.

Palavras-chave: ética, metafísica, psicologia, amor, desejo

\begin{abstract}
This paper deals with the distinction between love of friendship (or love of benevolence) and love of concupiscence in Thomas Aquinas' Summa Theologiae. It shows the relation between similarity and difference which the notion of love has with notions that form the distinction, namely concupiscence, desire, friendship and benevolence. It demonstrates that the foundations of Aquinas' theory of love have their basis in Aristotle's thought: the theory of appetite based on physical conception of psychology, the analogy between the distinction of love and the metaphysical division of being, the ethical origins of this distinction in the triple division of the concept of friendship: useful, pleasant and virtuous. This article also studies the uses of the distinction of love as love of friendship and love of concupiscence and investigates if it is appropriate to ascribe a double conception for this distinction as some intended.
\end{abstract}

Keywords: ethics, metaphysics, psychology, love, desire 
Ao longo da Idade Média, o pensamento cristão cunhou uma nomenclatura própria para designar uma distinção no interior da noção de amor, a saber: amor amicitiae (amor de amizade) e amor concupiscentiae (amor de concupiscência) ${ }^{1}$. No pensamento de Tomás de Aquino sobre a natureza do amor, essa distinção encontra-se presente desde a redação do seu comentário às Sentenças de Pedro Lombardo, em 1252 na sua primeira estada em Paris, até a produção de sua própria Suma de Teologia (ST), redigida quase vinte anos depois, por volta de 1271, na fase final de sua vida $^{2}$. Apesar de julgarmos importante o desenvolvimento de uma análise genética minuciosa sobre o uso da distinção do amor no pensamento medieval e também no conjunto da obra de Aquino, o presente artigo limitar-se-á - mas sem negligenciar a história dos conceitos e dos vocabulários - à busca de entendimento acerca da concepção e do uso que Tomás de Aquino fez dessa distinção no seu pensamento maduro, tal qual expresso na ST. Nessa obra, encontra-se um artigo que trata especialmente

\footnotetext{
1 A distinção diádica do amor surge por volta do século XII no contexto teológico da busca de entendimento dos problemas relativos ao amor a Deus. O problema central do amor a Deus pode ser formulado assim: pode o homem naturalmente amar a Deus mais do que a si mesmo, ou somente com o auxílio da graça? GUILLOU, 2009, p.286, sugere que, provavelmente, a distinção não apareceu antes da segunda metade do século XII, pois não há nenhuma menção a ela nas Sentenças de Pedro Lombardo, cuja redação terminou por volta de 1150 e que reunia as principais opiniões dos padres da Igreja e dos teólogos das Escolas. Segundo Guillou, pode-se constatar a presença da concepção da distinção na obra de Geoffroy de Poitier, no estudo do amor (dilectio) natural que ele divide em voluntário e involutário, onde o amor voluntário é dividido em concupiscência e amizade. Cf. GUILLOU, 2009, p.285286. A distinção assume a sua denominação clássica na Summa Aurea de Guillaume d'Auxerre, na qual a distinção, no interior do amor voluntário, é denominada dilectio amicitiae e dilectio concupiscentiae. 0 uso do vocabularío relativo à distinção diádica do amor a partir de então se difunde nas obras de alguns dos principais teólogos das escolas medievais que precederam à Tomás de Aquino: Filipe de Chancelier, Alexandre de Hales, Alberto Magno... Para acompanhar o desenvolvimento conceitual da distinção em meio às discussões teológicas dos séculos XII-XIII Cf. OSBORNE Jr, 2005, pois, no presente artigo, buscamos, ainda que sem ignorar o contexto teológico, apenas um entendimento da distinção diádica do amor no interior da antropologia de Aquino, mais propriamente no seu estudo sobre as paixões da alma humana. Assim, não trataremos do principal problema medieval concernente ao amor: o problema de saber como é possível amar a Deus acima de todas as coisas, inclusive de si mesmo. Embora a antropologia de Aquino esteja a serviço da teologia, em nosso estudo da distinção diádica do amor nos limitaremos a examinar os fundamentos aristotélicos, antes de propriamente considerar a sua utilização na teologia de Tomás de Aquino, o que nos remeteria, sobretudo, a um estudo da noção de caritas, i.e., do amor sobrenatural por Deus.

2 Digo quase vinte anos porque a prima secundae da ST, secção onde se encontram os artigos que constituem nosso principal objeto textual de estudo, foi escrita por volta de 1271 durante a sua segunda temporada em Paris. Também é interessante assinalar que no Scriptum super libros Sententiarum, i.e., no Comentário às Sentenças de Pedro Lombardo, Tomás de Aquino ainda utiliza a expressão dilectio concupiscentiae e dilectio amicitiae herdada dos escolásticos que 0 antecederam e não ainda amor amicitiae e amor concupiscentiae como encontramos na ST.
} 
da referida distinção, a saber, ST, Ia-IIae, q.26, a.4, intitulado Se o amor é convenientemente dividido em amor de amizade e amor de concupiscência, mas nela também se encontram outros artigos, igualmente na Ia-IIae, nos quais a distinção é diversamente caracterizada e aplicada, e.g., q.27, a.3 e q.28, a.1 e a.3. Esses artigos constituem a matéria textual primária de nosso estudo, cuja interpretação nos permitirá refletir não somente sobre a distinção entre amor de amizade e amor de concupiscência, mas também sobre a natureza do amor, do desejo e da amizade.

\section{Diferenças e semelhanças entre amor de amizade e amizade e entre amor de concupiscência e concupiscência}

A nomenclatura utilizada pela divisão do amor acrescenta dois qualificativos à noção de amor, a saber, "de amizade" e "de concupiscência", indicando que a distinção opera uma divisão no conceito do amor por meio dos vínculos que este mantém com outras duas noções que lhe são muito próximas: a concupiscência e a amizade. Por isso, julgamos que para se entender melhor a natureza do amor, assim como a natureza da distinção entre amor de amizade e amor de concupiscência, seria útil - antes de tratarmos da distinção em si mesma - identificarmos, na $\mathrm{ST}$, as semelhanças e as diferenças que o amor mantém com essas duas noções e com as noções correlatas do desejo e da benevolência.

Nas respostas às objeções da ST, Ia-IIae, q. 26, a.4, podemos notar a preocupação de Tomás de Aquino em discriminar a noção comum a que a divisão do amor em "de amizade" e "de concupiscência" se refere, i.e., a noção que expressa a natureza mesma do amor, daquelas noções das quais a divisão retirou os seus qualificativos, a saber, as noções que expressam a natureza da concupiscência e a natureza da amizade. Sobretudo o uso da expressão "amor de amizade" para designar um modo de amar, provavelmente inspirou em Tomás de Aquino um maior cuidado no distinguir entre amor e amizade, pois, apesar de os gregos utilizarem palavras de raízes diferentes, eros e philía, para designar amor e amizade, eles as utilizavam em sentidos tão amplos que cada uma delas, em sua significação, era capaz de cobrir grande parte das relações afetivas que designaríamos como sendo amor ou amizade. E embora os latinos tenham traduzido eros por amor, philía foi traduzida tanto por amicitia quanto por amor, e como as palavras latinas, amor e amicitia, possuem a mesma raiz, a 
possibilidade de utilizá-las como sinônimos, confundindo as naturezas por elas significadas, tornou-se acentuada ${ }^{3}$.

Assim, na ST, Ia-IIae, q.26, a.4, que introduz a divisão do ato de amar em amor de amizade e amor de concupiscência, Tomás de Aquino responde à duas objeções que pretendem mostrar que o amor não pode ser convenientemente dividido em amor de amizade e amor de concupiscência. A primeira objeção argumenta que, como o amor é uma passio (paixão), ele não pode ser divido em uma espécie que seja do gênero do habitus (hábito), como é o caso da amizade; enquanto que a segunda objeção mostra que embora o desejo seja uma paixão, ele é uma paixão ao lado do amor, mas não uma espécie do amor. Perante essas objeções, o procedimento de Tomás de Aquino consiste em aceitar a argumentação, mas rejeitar a conclusão, mostrando que o erro das objeções consistia em ter tratado o amor de amizade e o amor de concupiscência como se fossem sinônimos da amizade e da concupiscência. Assim, Aquino mostra que da argumentação das duas objeções não se segue a conclusão pretendida de que o amor não se divide em amor de amizade e de concupiscência, mas segue-se apenas que o amor não pode ser dividido em amizade e concupiscência, pois nas palavras de Tomás de Aquino "amor não se divide em amizade e concupiscência, mas em amor de amizade e de concupiscência"

Essas respostas às duas primeiras objeções supõem o resultado do artigo anterior, ST, Ia-IIae, q.26, a.3, em que Tomás de Aquino, ao analisar a significação dos quatro principais termos utilizados para designar o amor - amor, dilectio, amicitia e caritas -, faz uma nítida distinção entre o que é da natureza do "actus vel passionis" e o que é da natureza do "habitus". Nesse contexto, actus vel passionis, significa o ato/paixão de uma potência natural da alma, a faculdade apetitiva, a qual, por ser uma potência passiva, precisa receber (passio) a ação de um agente, i.e., a ação do bem

\footnotetext{
${ }^{3}$ Louis-André Dorion, comentando a sua própria tradução do Lysis de Platão, afirma que: "(amizade) corresponde somente a uma das relações que o termo philía designa. Para os gregos, a philía representa relações tão variadas e numerosas como as relações familiares, as ligações amorosas, os laços de amizade, a afeição pelos animais, o apego aos objetos inanimados, e mesmo, no domínio da física, a atração mútua dos elementos (ne correspond en fait qu'à l'une des relations que désigne le terme philía. Pour les Grecs, ressortissent à la philía des relations aussi variées et nombreuses que les rapports familiaux, les liaison amoureuses, les liens d'amitié, l'affection pour les animaux, l'attachement à des objets inanimés et même, dans le domaine de la physique, l'attraction mutuelle des élements)". (PLATON, 2004, p.159). Ursula Wolf em seu estudo sobre Aristóteles declara que "... deve-se observar que a palavra grega philía tem um emprego mais amplo que nossa palavra amizade. Sendo assim Aristóteles considera que também a relação dos pais com os filhos ou a relação entre cônjuges representa um caso de philía". (WOLF, 2007, p. 224)

${ }^{4}$ ST, la-llae, q.26, a.4, ad1: "... quod amor nom divitur per amicitiam et concupiscentiam, se per amore amicitiae et concupiscenciae".
} 
apreendido, para que a sua potência seja atualizada (actus) no ato de amar, enquanto que habitus significa a disposição adquirida para agir (habitus operativo) de modo virtuoso ou vicioso. Nessa passagem do a.3, Tomás de Aquino coloca, de um lado, os nomes amor, que designa o amor em geral (natural, sensitivo e intelectivo), e dilectio, que designa propriamente o amor intelectivo, afirmando que ambos significam ao modo de "actus vel passionis" e, de outro lado, põe amicitia, afirmando que ela é um "quasi habitus". Quanto à caritas, Tomás de Aquino afirma que esta é significada de ambos os modos, i.e., tanto como um habitus quanto como um "actus vel passionis" . Assim, levando em conta a distinção estabelecida entre "actus vel passionis" e "quasi habitus", podemos ver que as respostas de Tomás de Aquino, às duas primeiras objeções, demonstram, em primeiro lugar, que a dupla divisão se aplica ao amor, i.e., ao que é da natureza do "actus vel passionis", enquanto que a amizade pertence à natureza do habitus, e, em segundo lugar, que embora a concupiscência pertença ao gênero do que é “actus vel passionis" do mesmo modo que o amor, ela não é uma espécie do amor, mas uma paixão distinta do amor dentro do gênero do que é da natureza do "actus vel passionis".

Embora - como acabamos de ver - Tomás de Aquino distinga nitidamente entre, por um lado, o ato/paixão do amor (que inclui a distinção amor de amizade e amor de concupiscência) e, por outro lado, o habitus da amizade e a paixão da concupiscência (que não comportam nem fazem parte de tal distinção), o fato do amor ser dividido em "de amizade" e "de concupiscência" revela que a noção de amor mantém um vínculo com essas outras duas noções e que a elas se assemelha. Essa similitude é realçada no sed contra do artigo:

Em sentido contrário dizemos que amamos certas coisas porque as desejamos (concupiscimus), assim como 'se diz que alguém ama o vinho porque deseja a sua doçura' segundo o livro II dos Tópicos. Ora, não temos amizade (amicitia) pelo vinho e coisas semelhantes conforme nos diz o livro VIII da Ética. Logo, uma coisa é o amor de concupiscência e outra o amor de amizade 6 .

\footnotetext{
${ }^{5}$ Caritas é o termo latino que traduz ágape, o termo grego utilizado pelos evangelistas para designar o novo amor transmitido por Jesus Cristo. Para Tomás de Aquino, caritas é um habitus infuso sobrenaturalmente por Deus no apetite intelectivo cujo ato próprio é o amor. Ela é uma amizade com Deus por meio da qual ama-se todas as criaturas de Deus por amor a Deus.

${ }^{6}$ ST, la-llae, q.26, a.4: "Sed contra, quaedam dicimur amare quia ea concupiscimus: sicut dicitur aliquis amare vinum propter dulce quod in eo concupiscit, ut ad huiusmodi, non habemus amicitiam, ut dicitur in VIII Ethic. Ergo alius est amor concupiscentiae, et alius est amor amicitiae".
} 
Assim - uma vez tendo-se distinguido nitidamente a natureza do amor das naturezas da amizade e da concupiscência -, pode-se buscar entendimento acerca do que está sendo significado pela distinção do amor em "de amizade" e "de concupiscência", examinando a relação que a noção de amor mantém com as noções da amizade e da concupiscência, contemplando não apenas as suas diferenças, mas também as suas semelhanças.

\section{A tripla divisão do amor segundo a tripla divisão do apetite e a distinção entre amor, desejo e concupiscência}

Seguindo o Perì Psichés (De anima) de Aristóteles, Tomás de Aquino divide as potências da alma em potência vegetativa, sensitiva, intelectiva, apetitiva e locomotiva ${ }^{7}$. A potência sensitiva e a intelectiva são potências apreensivas, ou cognitivas, que apreendem a forma sensível ou inteligível das coisas, enquanto a potência apetitiva é a faculdade da alma por meio da qual o homem se dirige às próprias coisas na medida em que foram apreendidas como boas ou como más. É importante frisar que a potência apetitiva sempre supõe a apreensiva, pois não pode haver apetite de algo indeterminado ou completamente desconhecido. A potência apetitiva divide-se entre os apetites que seguem à apreensão própria do apetecente (apetite sensitivo, consequente à apreensão sensível, e apetite intelectivo, consequente à apreensão intelectual) e o apetite que segue apenas à natureza do apetecente (apetite natural ${ }^{8}$ ). Assim, a faculdade apetitiva dirige-se às coisas ou pela mera inclinação da sua forma natural (eidos, specie) ou pela inclinação produzida no apetite (sensitivo ou intelectivo) após a faculdade apreensiva (sensitiva ou intelectiva) ter apreendido a forma (sensível ou inteligível) de uma coisa e tê-la considerado como um bem ou como um mal, buscando, a seguir, a concretização de uma união real com o que é considerado um bem e o afastamento do que é considerado um mal ${ }^{9}$.

Para obter uma compreensão da natureza do amor e da dinâmica da parte apetitiva da alma, Tomás de Aquino aplica, de modo geral, os princípios da Física aristotélica - os quais se referem originalmente aos

\footnotetext{
7 Ver ST, I, q.78, a.1 e o Commentaire du traité de l'âme d'Aristote, II, cap. V, p.156.

${ }^{8}$ Embora 0 apetite natural não siga a apreensão do apetecente, ele também supõe a apreensão, mas a apreensão de Deus que, enquanto Inteligência Criadora, determinou a natureza de todas as coisas.

${ }^{9}$ É importante assinalar que a faculdade apetitiva sensitiva se divide em concupiscivel e irascível, de tal modo que 0 apetite sensitivo concupiscível diz respeito ao bem e ao mal simplesmente, enquanto que 0 apetite sensitivo irascível visa ao bem e a ao mal enquanto árduos.
} 
movimentos dos corpos naturais - aos movimentos interiores das paixões do apetite humano, o que implica na caracterização das faculdades apetitivas da alma como potências passivas na medida em que precisam ser postas em ato pela ação de um agente. Uma vez que as faculdades apetitivas dirigemse às coisas segundo elas sejam apreendidas enquanto boas ou enquanto más, e como o bem é ontologicamente anterior ao mal, o bem é que é considerado o agente do ato primeiro do apetite e, portanto, a sua causa própria, seja o bem natural para o qual a inclinação da natureza dirige o apetite, seja o ente apreendido como um bem sensível ou inteligível. E é justamente esse ato primeiro do apetite, ou essa primeira mudança sofrida no apetite pela ação do bem, que Tomás de Aquino considera como sendo propriamente o amor, o qual é denominado tanto ao modo de paixão, como prima imutatio, quanto ao modo de ato, como actus primus, do apetite em geral.

Uma vez tendo identificado o amor ao ato primeiro da potência apetitiva em geral - e antes de introduzir, no a.4, a divisão do ato de amar em amor de amizade e amor de concupiscência - Tomás de Aquino apresenta, na ST, Ia-IIae, q.26, a.1-2, uma tripla divisão do amor de acordo com a divisão tripartida das potências apetitivas da alma: "O amor é algo próprio do apetite, pois ambos têm o bem por objeto. Daí que segundo seja a diferença do apetite, tal é a diferença do amor" ${ }^{\text {"10 }}$. Assim, o amor pode ser dividido em três espécies de acordo com o apetite do qual ele seja o ato/paixão: amor natural no apetite natural, amor sensitivo no apetite sensitivo e amor intelectivo no apetite intelectivo, ou vontade.

Quando o amor acontece no apetite natural, Tomás de Aquino o caracteriza pelo termo connaturalitas e, quando ocorre nos apetites baseados na cognição própria do apetecente, i.e., no apetite sensitivo e no intelectivo, caracteriza-o por meio dos termos complacentia, coaptatio, adaptatio ou proportio. Esses termos, de modo geral, indicam que o amor é um certo comprazer-se com o bem apreendido que adapta, ou proporciona, o apetite para o bem amado, inclinando-o em direção a esse bem. Além do que, ao descrever a dinâmica circular do apetite, Tomás de Aquino estabelece uma nítida distinção entre a natureza do amor, considerada como uma inclinação do apetite para o bem, e a natureza do desejo, considerada como um movimento do apetite para o bem. Comparando a dinâmica do apetite com a dinâmica dos corpos naturais, Aquino afirma que o agente natural, a coisa apreendida como bem, causa no apetite uma inclinação para

10 ST, la-llae, q.26, a.1: "... quod amor est aliquid ad appetitum pertinens: cum utriusque obiectum sit bonum Unde secundum differentiam appetitus, est diferentia amoris". 
a ação, que é denominada amor, a qual, por sua vez, causa no apetite um movimento para a ação, o qual é denominado desiderium (desejo), devido a ausência do bem amado. Mas é somente após a execução da ação, se a ação obtiver sucesso, que o apetite alcança um repouso, que é denominado gaudium (a alegria), obtido na união com a presença do bem amado ${ }^{11}$. Assim, podemos assinalar que amor e desejo são "actus vel passionis" presentes tanto no apetite sensitivo quanto no apetite intelectivo, mas que o amor tem prioridade causal sobre o desejo, sendo por isso também chamado por Aquino de principium motus do apetite em geral, ou raiz das paixões do apetite, pois ele é a causa primeira, no interior do apetite, não só do desejo, mas também das demais paixões a que o apetite está sujeito ${ }^{12}$.

Quanto à concupiscência propriamente dita, Tomás de Aquino deixa claro na ST, Ia-IIae, q.30, que ela pertence apenas ao apetite sensitivo, pois ela é a forma sensitiva de desiderium (desejo), o qual podendo ser sensitivo ou intelectivo é denominado de concupiscentia quando no apetite sensitivo. No a.1, dessa mesma questão, Tomás de Aquino apresenta a caracterização de concupiscência citando Aristóteles - "concupiscentia est appetitus delectabilis (concupiscência é apetite do deleitável)" - e, após explicar que o deleitável pode ser tanto um bem sensível quanto um bem inteligível, precisa que a concupiscência em sentido estrito se refere ao apetite sensitivo concupiscível, pertencendo ao composto de corpo e alma, e apenas em sentido lato à vontade. A resposta à segunda objeção, contida nesse artigo, mostra que concupiscência para Tomás de Aquino é uma espécie de desiderium (desejo), a saber, o desejo do apetite sensitivo concupiscível: “... deve-se dizer que o desejo, propriamente falando, pertence não só ao apetite inferior, mas também, e com mais propriedade, ao superior. Pois não implica, como a concupiscência, uma associação no desejar, mas um simples movimento em direção à coisa desejada ${ }^{13}$ ". Assim, desejo é uma

\footnotetext{
11 Segundo Tomás de Aquino, a paixão do amor se refere ao bem simplesmente, sem estar condicionado à presença ou à ausência do bem amado, e sendo propriamente uma complacentia no bem apetecível, o amor já é uma certa união afetiva, no interior do apetite do amante, com o bem amado. Por outro lado, a paixão do desejo somente tem como objeto o bem amado na medida em que ele é apreendido como ausente, e já constitui um movimento da alma em direção ao bem amado visando a união real, exterior, com ele.

${ }^{12}$ Cf. ST, la-llae, q.25, a.2, Se o amor é a primeira paixão do concupiscível e q.27, a.4, Se alguma outra paixão da alma é causa do amor.

${ }_{13} \mathrm{ST}$, la-llae, q.30, a.1, ad2: "Ad secundum dicendum quod desiderium magis pertinere potest, proprie loquendo, non solum ad inferiorem appetitum, sed etiam ad superorem. Nom enim importat aliquam consociationem in cupiendo, sicut concupiscentia; sed simplicem motum rem desideratam". É importante assinalar que "consociationem" diz respeito ao fato de a concupiscência ser uma paixão propriamente dita, pertencendo, portanto, ao homem enquanto composto de corpo e alma.
} 
paixão da alma que quando ocorre no apetite sensitivo designa uma paixão em sentido estrito, sendo propriamente denominada de concupiscência, ou cupidez (cupiditas); entretanto, quando ocorre no apetite intelectivo, ou vontade, não é uma paixão em sentido próprio, mas apenas em sentido lato e, nesse caso, é designado pelo termo desiderium. Contudo, do ponto de vista formal, na dinâmica do apetite desencadeada pela apreensão de algum ente como um bem, tanto concupiscentia quanto desiderium se referem ao bem enquanto ausente, diferenciando-se assim do amor, que, como vimos, visa ao bem simplesmente e apenas dispõe o apetite inclinando-o para o bem, causando, no interior do próprio apetite, a concupiscentia ou o desiderium por esse mesmo bem. Sendo que é somente na posse do bem amado presente, na união real com ele, que o apetite repousa em deleite e alegria (gaudium). Na teoria das paixões de Tomás de Aquino, se o amante não alcança o bem amado, então sobrevêm a tristitia (tristeza), mas se ainda há esperança (spes) de obtê-lo, o amante fará todos os seus esforços em direção ao bem desejado - agora considerado como um bem árduo - até que alcance a alegria do deleite no bem amado. Mas, se ainda assim ele não obtém sucesso nos seus esforços, então sobrevém a desesperança (desesperatio) e, logo a seguir, a tristeza, ou dor ${ }^{14}$.

É importante chamar atenção para o fato de que as declarações feitas por Tomás de Aquino, na ST, Ia-IIae, q.26, a.2, de que o amor é uma paixão e de que o amor pertence ao concupiscível poderiam levar ao engano de se pensar que amor - assim como a concupiscência propriamente dita pertenceria apenas ao sensitivo ou propriamente ao sensitivo. No tocante a paixão, o engano poderia surgir pelo fato de que, na ST, Ia-IIae, q.22, a.1, Aquino elenca três sentidos de paixão (amplo, próprio e mais que próprio), e restringe o sentido próprio e mais que próprio ao sensitivo, referindo-se a uma afecção do corpo que acidentalmente pertence à alma. Contudo, é preciso levar em conta que, na ST, Ia-IIae, q.26, a.2, Aquino está expondo uma teoria do amor como ato/paixão do apetite em geral, e ao declarar que o amor é uma paixão, o Aquinate está afirmando que amor é uma paixão no sentido amplo de mera recepção, significando - como já vimos - que o amor é o "actus vel passionis" do apetite em geral. Também a declaração de que o amor pertence ao concupiscível poderia levar a pensar que amor

\footnotetext{
14 É importante precisar que, na dinâmica das paixões, a causa da tristeza é mais propriamente a presença do mal do que a ausência do bem, e mesmo quando consideramos a perda do bem como causa da tristeza é preciso assinalar que sofremos mais pela perda dos bens com os quais já nos deleitamos do que com a perda dos que ainda não possuímos. A esse respeito Cf. ST, la-llae, q.30, a.2, Se a concupiscência é causa da dor.
} 
diz respeito apenas ao apetite sensitivo, pois - uma vez que o apetite sensitivo se divide em concupiscível e irascível, enquanto o apetite intelectivo não comporta tal divisão ${ }^{15}$ - poder-se-ia concluir erroneamente que o amor seria uma ocorrência própria apenas do apetite sensitivo concupiscível. Contudo, na ST, Ia-IIae, q.26, a.1, ao apresentar a tripla divisão do amor de acordo com a tripla divisão do apetite, Tomás de Aquino deixa claro que, em sentido amplo, concupiscível aplica-se também à vontade na medida em que ela visa ao bem simplesmente, seja ele árduo ou não: "logo o amor sensitivo está no apetite sensitivo, como o amor intelectivo no apetite intelectivo. E pertence ao concupiscível porque é dito com respeito ao bem absolutamente e não com respeito ao bem árduo, que é objeto do irascível"16. Além disso, na ST, I, q.82, a.5, ad 2, encontra-se uma passagem em que Tomás de Aquino explicitamente menciona o uso de concupiscível em sentido amplo aplicado à vontade: "deve-se dizer que a vontade pode ser chamada de irascível, na medida em que quer combater o mal não por um impulso passional, mas por um juízo da razão. Igualmente pode ser chamada de concupiscível, enquanto é desejo do bem" ${ }^{\prime 17}$.

Assim, as afirmações contidas na ST, Ia-IIae, q.26, a.2, de que o amor pertence ao concupiscível e que ele é uma paixão, devem ser entendidas em sua significação ampla, permitindo que amor designe o ato primeiro das potêncas apetitivas em geral (natural, sensitiva e intelectiva, ou vontade).

\section{A tripla divisão aristotélica da philía segundo a divisão dos bens e 0 papel da benevolência no amor de amizade e na genuína amizade}

Até agora vínhamos examinando apenas um dos ramos da divisão do amor em "de amizade" e "de concupiscência", aquele em que o conceito do amor, que diz respeito a algo que é da natureza do ato/paixão, mantém uma

\footnotetext{
$15 \mathrm{O}$ apetite intelectivo se refere ao bem e ao mal simpliciter sob sua noção universal, sendo capaz de desempenhar as funções relativas à arduidade ou não arduidade de um bem ou de um mal sem precisar se dividir como o apetite sensitivo que, para dar conta da facilidade ou dificuldade de uma ação particular com relação ao bem e ao mal sensíveis apreendidos, precisa se dividir em concupiscivel e irascível. Cf. ST, I, q.81, a.2, Se o apetite sensitivo se divide em irascível e concupiscível como sendo potências diferentes, e ST, I, q.82, a.5, Se deve-se distinguir a potência irascivel e a concupiscivel no apetite superior.

${ }^{16} \mathrm{ST}$, la-llae, q.26, a.1: "Amor igitur sensitivus est in appetito sensitivo, sicut amor intellectivus in appetito intellectivo. Et pertinet ad concupiscibilem: quia dicitur per respectum ad bonum absolute, non per respectum ad arduum, quod est obiectum irascibilis".

17 ST, I, q.82, a.5, ad 2 "Ad secundum dicendum quod ipsa voluntas potest dici irascibilis, prout vult impugnare malum, nom ex impetu passionis, sed ex iudicio rationis. Et eodem modo potest dici concupiscilis, propter desiderium boni (...)".
} 
relação com algo que também é da natureza do ato/paixão, a saber, a concupiscência ou desejo. Mas, a partir de agora, vamos estudar o outro ramo da distinção, aquele em que a noção de amor mantém uma relação com algo que é da natureza do habitus: a amizade.

No artigo que tem sido o objeto central de nossa análise - ST, I, q.26, a.4 - é somente na reposta à terceira objeção (ad 3) que Tomás de Aquino menciona a teoria que provavelmente esteja na origem da divisão do amor em "de amizade" e "de concupiscência", a saber: a tripla divisão aristótélica da philía (amor, amicitia) de acordo com uma tripla divisão do bem, a saber: a amicitia utilis, ou amizade fundada no bem útil, que é a amizade utilitária; a amicitia delectabilis, que é a amizade fundada no bem deleitável, ou no prazer, e a amicitia honesta, ou amizade fundada no bem propriamente dito, ou bem por si, que é a amizade virtuosa ${ }^{18}$. A terceira objeção (ad 3) pretende que não há uma oposição entre amizade e concupiscência porque as amizades do útil e do deleitável supõem a concupiscência. Em sua resposta, Aquino explica que as amizades que supõem o amor de concupiscência - as amizades baseadas no prazer e na utilidade - possuem algo da noção de amizade na medida em que querem bem ao amigo, mas na medida em que terminam por remeter este bem querer ao próprio amante, afastam-se da noção da verdadeira amizade. Nessa breve resposta de Tomás de Aquino, podemos encontrar os elementos que indicam por que a tripla divisão aristotélica da philia se encontra na origem da divisão que estamos estudando e por que o "amor de amizade" tem como sinônimo a expressão "amor de benevolência". Da resposta de Aquino, podemos inferir que a amizade do útil e do prazer supõe um amor de concupiscência, no qual o outro é amado não por ele mesmo, mas em vista de outro bem, a saber, em vista da utilidade ou do prazer que o amigo/amado proporciona ao amante e, por isso, nesses casos, não se pode estabelecer uma genuína amizade entre os envolvidos. Nesses tipos de amizade, também não encontramos a verdadeira benevolência (eunóia, benevolentia), i.e., o genuíno

\footnotetext{
18 Traçando o desenvolvimento histórico da distinção do amor em "de amizade" e "de concupiscência", é importante assinalar a tendência da divisão triádica de Aristóteles a assumir uma forma diádica, na medida em que tanto 0 amar em vista do útil quanto o amar em vista do prazer podem ser reunidos como formas de amar algo não por si, mas por outro. Podemos ver esse movimento se desdobrar na distinção estoica entre utile e honestum até chegar à famosa distinção de Agostinho entre uti e frui, que articula a ordo amoris agostiniana entre o que deve ser amado por si (propter se) com amor frui, e o que deve ser amado por outro (propter aliud) com amor uti. Assim, por meio de cupiditas o homem é levado a amar ao mundo antes do que a Deus, mas querendo fruir do que é efêmero só encontra decepção e insatisfação, enquanto que, por meio de caritas, o homem é levado a amar primeiramente a Deus com amor frui e a amar ao mundo com amor uti, i.e., em vista de Deus, buscando e encontrando genuína satisfação somente no que é eterno, i.e., em Deus. Cf. AGOSTINHO, Santo. A doutrina cristã, I e Cf. ARENDT, 1929, p.52.
} 
querer o bem ao outro, pois embora no amor de concupiscência possamos querer bem ao outro - e.g., que ele viva, que tenha saúde, que tenha riquezas, etc. -, desejamos esses bens ao outro porque queremos o outro como um bem para nós mesmos, na medida em que ele nos será de alguma utilidade ou nos proporcionará algum prazer. Por outro lado, na amizade honesta, também chamada de amizade virtuosa, ou amizade segundo a virtude, o amigo é amado por si mesmo, i.e., pelo que ele é, e não por causa de alguma outra coisa ou por causa do prazer que ele proporciona ao amante, o que permite a possibilidade de estabelecer-se uma verdadeira amizade. Nesse caso, a afetividade do amante expressa uma genuína benevolência para com o amigo, pois ele quer o bem para ele por ele mesmo e não para que reverta em algum bem para si mesmo ou para outra pessoa. Assim podemos notar a proximidade do amor de amizade com a amizade e a benevolência, na medida em que a genuína amizade supõe o amor de amizade e este supõe a benevolência.

Na ST a amizade é fundamentalmente estudada com vistas ao entendimento da virtude teologal da caridade (caritas, agape), i.e., da amizade com Deus que se estende em amor ao próximo de modo universal. Assim, é justamente na secção da ST dedicada à caridade que podemos encontrar uma caracterização da autêntica amizade como sendo uma amizade fundada no amor de amizade, ou de benevolência, uma vez que este é um amor com genuína benevolência:

(...) não é qualquer amor que realiza a noção de amizade, mas o amor com benevolência, pelo qual queremos bem a quem amamos. Se, porém, não queremos o bem às coisas amadas, mas queremos o bem delas para nós mesmos, como quando dizemos amar o vinho, ou o cavalo etc, não há amor de amizade (amor amicitiae), mas de concupiscência ${ }^{19}$.

Assim, podemos notar como da ideia de um amor com concupiscência, i.e., de um amor que quer o bem do outro não por ele mesmo, desenvolve-se a noção de amor concupiscentiae como fundamento das amizades fundadas na utilidade e no prazer, e como da ideia de um amor com benevolência,, i.e., de um amor que quer o bem do outro por ele mesmo, desenvolve-se a noção de amor

\footnotetext{
${ }^{19}$ ST, Ila-llae,, q.23, a.1: "Respondeo dicendum quod, secundum Philosophum, inVIII Ethic., non quilibet amor habet rationem amicitiae, sed amor qui est cum benevolentia: quando scilicet sic amamus aliquem ut ei bonum velimus. Si autem rebus amatis non bonum velimus, sed ipsum eorum bonum velimus nobis, sicut dicimur amare vinum aut equum aut aliquid huiusmodi, non est amor amicitiae, sed cuiusdam concupiscentiae".
} 
amicitiae como base da genuína amizade, sendo por isso não apenas chamado de amor de amizade, mas também de amor de benevolência.

No que diz respeito à diferença entre "amor de amizade", que é da natureza do ato/paixão, e "amizade", que é da natureza do habitus, é importante salientar que embora o amor de amizade, ou de benevolência, seja uma condição necessária para a genuína amizade, não é condição suficiente, pois a amizade exige outras condições para que possa de fato se estabelecer. Seguindo Aristóteles, Tomás de Aquino elenca como condições que são necessárias ao estabelecimento da amizade: a reciprocidade, o reconhecimento, a concórdia e a benevolência. Assim, para termos uma verdadeira amizade, não basta o amor de amizade com sua genuína benevolência para com o amigo, mas é preciso que essa benevolência seja mútua, i.e., que ambos os amigos queiram genuinamente o bem um do outro e se amem mutuamente com amor de amizade, e esse amor de amizade não pode ser secreto, pois tem de haver reconhecimento mútuo para que a amizade possa ocorrer ${ }^{20}$. Além disso, a amizade supõe certa concórdia entre as opiniões dos amigos e também precisa estabelecer-se por meio de atos concretos, daí a beneficência, i.e., o não apenas querer, mas também fazer o bem, e isto ao longo de um convívio fundado na prática da virtude.

\section{A fórmula aristótélica "amar est vele alicui bonum" e a ordenação segundo "per prius e per posterius" do duplo tender do ato de amar: amar um bem por outro e amar um bem por si}

A distinção entre amor de amizade e amor de concupiscência é caracterizada, de modo geral, na ST, Ia-IIae, q.26, a.4, cujo artigo foi intitulado Se amor é convenientemente dividido em amor de amizade e amor de concupiscência. $\mathrm{O}$ corpo da resposta desse artigo está dividido em dois parágrafos. $\mathrm{O}$ primeiro caracteriza a distinção, e o segundo discorre sobre ela. Eis o primeiro:

Como afirma o filósofo no livro II da Retórica, "amar é querer bem a alguém". Assim, pois, o movimento do amor tende para duas coisas, a saber, para o bem que se quer para alguém, ou para si ou para outro, e para aquele para quem se quer o bem. Ora, para o bem que se quer para outrem tem-se amor de

${ }^{20}$ Cf. Commentary on Aristotle's Nicomachean Ethics, VIII, 1560, p.481 e ST, II-Ilae, q.23, a.1 
concupis-cência, e para aquele para quem se quer o bem tem-se amor de amizade ${ }^{21}$.

Embora, como já mencionamos, a divisão do amor tenha sido cunhada na Idade Média e, como tal, não esteja presente em Aristóteles, Tomás de Aquino, nessa passagem, extrai a distinção de uma análise da fórmula aristotélica relativa à philía. Como pode ser notado, nessa fórmula $\mathrm{o}$ ato de amar é estruturado não apenas sobre dois elementos, o amante e o amado, mas sobre três elementos: o amante, o bem que se quer para alguém e aquele para quem se quer o bem. Como todo amor tem como objeto próprio o bem, pode-se distinguir nessa fórmula dois tenderes do amante em relação a dois bens no ato de amar: um tender em direção ao bem amado que se quer, relativamente, como bem para alguém, e que é amado com amor concupiscentiae, e outro tender em direção ao bem amado que é aquele para quem se quer, absolutamente, o bem, e que é amado com amor amicitiae.

No segundo parágrafo, Aquino explica como estes dois tenderes do amor se encontram ordenados no ato de amar, explicitando os fundamentos do amor em uma metafísica do bem:

Esta divisão, porém, é por anterioridade e posterioridade, pois o que é amado com amor de amizade é amado de modo absoluto (simpliciter) e por si (per se); mas o que é amado por amor de concupiscência, não é amado de modo absoluto e por si, mas é amado por outrem (amatur alteri). Ora, como é ente absolutamente (ens simpliciter) o que tem o ser (quod habet esse); e ente relativo (ens secundum quid) o que existe em outro (quod est in alio); assim também o bem, que é conversível com o ente, (bonum simpliciter) de modo absoluto é o que tem a própria bondade, ao passo que o bem por outro (bonum alterius) é um bem relativo (bonum secundum quid). Por consequência, o amor pelo qual alguém é amado pelo bem dele é amor de modo absoluto (amor simpliciter), enquanto que o amor pelo qual algo é amado pelo bem de outrem é amor relativo (amor secundum quid). ${ }^{22}$.

\footnotetext{
${ }^{21}$ ST, la-Illae, q.26, a.4: "Respondeo dicendum quod, sicut Philosophus dicit in II Rhetoric., amare est velle alicui bonum. Sic ergo motus amoris in duo tendit: scilicet in bonum quod quis vult alicui, vel sibi vel alii; et in illud cui vult bonum. Ad illud ergo bonum quod quis vult alteri, habetur amor concupiscentiae: ad illud autem cui aliquis vult bonum, habetur amor amicitiae".

22 ST, la-lllae, q.26, a.4: "Haec autem divisio est secundum prius et posterius. Nam id quod amatur amore amicitiae, simpliciter et per se amatur: quod autem amatur amore concupiscentiae, non simpliciter et secundum se amatur, sed amatur alteri. Sicut enim ens simpliciter est quod habet esse, ens autem secundum quid quod est in alio; ita bonum, quod convertitur cum ente, simpliciter quidem est quod ipsum habet bonitatem; quod autem est bonum alterius, est bonum secundum quid. Et per consequens amor
} 
Para entender melhor essa divisão do ato de amar, Tomás de Aquino estabelece um paralelo ${ }^{23}$ entre duas analogias: a analogia do ente - na relação entre substância (o ente por si) e acidente (o ente que inere em outro) - e a analogia do bem - na relação entre bonus simpliciter, o bem que é querido por si, e bonus alterius, o bem que é querido por outro - $\mathrm{e}$ infere, a partir delas, uma analogia correspondente no amor. Ora, como o amor é o ato primeiro da faculdade apetitivaem geral - a qual, como vimos, se dirige prioritariamente ao bem -, pode-se estabelecer uma correspondente analogia para o amor, na medida em que o amor visa um bonus secundum quid no amor de concupiscência e visa um bonus simpliciter no amor de amizade. Desse modo, a correspondência entre as analogias pode ser descrita da seguinte forma: assim como há no ente um ens simpliciter (a substância) e um ens secundum quid (acidente), também há no amor um amor simpliciter que se dirige a um bonus simpliciter (no qual se ama alguém por si mesmo) e um amor secundum quid que se dirige a um bonus alterius (no qual se ama algo ou alguém não por si mesmo mas por outro).

Entre esses dois amores há uma ordenação "secundum prius et posterius" semelhante à que há entre a substância e o acidente e entre à que há entre um bem simpliciter e um bem secundum quid. Pois assim como o acidente (o ser por outro) só tem ser por inerência na substância (o ser por si), e assim como um bonum secundum quid (um bem amado por causa de outro) só tem bondade na medida em que está ordenado para alcançar um bonus simpliciter (um bem por si), também o amor de concupiscência é subsidiário do amor de amizade, pois um bem só é amado, com amor de concupiscência, na medida em que ele se destina, com amor de amizade, a alguém, i.e., a uma pessoa, seja essa pessoa amada o próprio amante, no caso do amor de si, ou seja, uma outra pessoa amada, no caso do amor de outrem. De acordo com esta ordenação, podemos deduzir que amor se diz em sentido primário do amor de amizade e somente em sentido derivado do amor de concupiscência, pois se ama "verdadeiramente" a quem se ama com amor de amizade, uma vez que o amor de concupiscência, por algo ou alguém, sempre estará a serviço do amor de amizade, seja o amor de amizade que se tem por si mesmo ou por outra pessoa. Do mesmo modo alguém só é "verdadeiramente" amado quando é amado com amor de

quo amatur aliquid ut ei sit bonum, est amor simpliciter: amor autem quo amatur aliquid ut sit bonum alterius, est amor secundum quid".

${ }^{23}$ O paralelo funda-se na conversibilidade entre ente e bem, segundo a qual o bem é o ente enquanto apreendido como bem e tornado objeto do apetite. Cf. Quaestione Disputatae De Veritate, q.1, a.1, onde podemos ler: "o ajustar-se do ente ao apetite é expresso pela palavra bem". LAUAND, 1999, p.147. 
amizade, na medida em que é amado não em vista de outra coisa ou de outro alguém, mas somente por si mesmo.

\section{Amor de carência e amor de doação: amar o outro como um bem que se quer para si e amar 0 outro como um bem para 0 qual se quer 0 bem por si}

Contudo, em outras partes da ST, encontramos passagens que poderiam sugerir a existência de outra concepção da divisão do amor em "de concupiscência" e "de amizade", além daquela extraída da fórmula do amor presente na Retórica de Aristóteles - "amar est velle alicui bonum" -, conforme apresentada na ST, I, q.26, a.4. Na análise dessa fórmula - como acabamos de ver - o amor de concupiscência é caracterizado como o ato de amar algo não por si, mas por outro, podendo esse outro ser o próprio amante ou outra pessoa, o que permite que nem todo amor de amizade seja por outra pessoa, mas que haja amor de amizade por si mesmo, assim como permite que o amor de concupiscência esteja a serviço não apenas do amor de si, mas também a serviço do amor de outrem. Contudo, em outros artigos da ST encontram-se passagens em que, por um lado, o amor de concupiscência é caracterizado como se curvando sobre o próprio amante sem mencionar a possibilidade desse amor ter seu término em outra pessoa, i.e., sem considerar a possibilidade de algo ser amado com amor de concupiscência por outra pessoa que não o próprio amante - e, por outro lado, o amor de amizade é caracterizado como saindo para fora de si - sem mencionar a possibilidade de um amor de amizade por si mesmo. Gostaríamos de destacar três passagens da ST que mostram essa outra abordagem acerca da divisão $0^{24}$, a saber: ST, Ia-IIae, q.27, a3, que trata da similitude como causa do amor, e ST, q.28, a.1 e a.3, que tratam, respectivamente, da união e do êxtase como efeitos do amor. Esses artigos como veremos - contém um rico material para o entendimento da distinção em questão, pois além de fornecerem exemplos de aplicações da distinção, fornecem-nos outras caracterizações da natureza e da dinâmica do amor por meio das noções de similitude, união e êxtase. No entanto, é importante investigarmos se estamos realmente diante de uma nova concepção da

\footnotetext{
${ }^{24}$ É importante salientar que essa outra abordagem não consiste em nenhuma novidade no âmbito do pensamento medieval, pelo contrário, ela é a forma com que a distinção costumava aparecer nos escolásticos anteriores a Tomás de Aquino. Esses dois usos da distinção, que encontramos na ST, já estão presentes no pensamento de Aquino sobre o amor desde o seu Comentário às Sentenças de Pedro Lombardo.
} 
distinção, como sugeriram alguns comentadores, ou se estamos apenas diante de outro uso da mesma concepção.

Após considerar que o bem (a.1) apreendido (a.2) é causa própria do amor - o que supõe a apreensão de uma similitude cognitiva do amado pelo amante - Tomás de Aquino, no a.3, afirma que a similitude ontológica também é causa do amor. A esse respeito Aquino explica que há dois tipos de similitude ontológica entre as coisas, a similitude em ato e a similitude em potência, que causam dois atos distintos de amor. Quando o amante é atraído pelo amado por uma similitude em potência, ele tem amor de concupiscência pelo amado, pois ama com a inclinação de obter o amado como um bem capaz de atualizar alguma potencialidade sua. Assim, no amor de concupiscência, a pessoa é amada fundamentalmente como um bem que o amante quer para si a fim de suprir alguma carência da sua parte. Por exemplo, um aprendiz ama o seu professor porque este, ao lhe ensinar um determinado conteúdo, atualiza a sua potencialidade para aprender aquela matéria. Por outro lado, quando o amante é atraído pelo amado por uma similitude em ato, o amante sente-se como que unificado ao amado e não deseja obter dele algo de que tenha carência, mas apenas doar ou compartilhar com ele o bem que possui. Assim, no amor de amizade, a pessoa é amada como um bem por si para o qual o amante quer doar ou compartilhar seus bens. Ao exemplo anteriormente citado, poderíamos acrescentar, então, que o aluno ama o professor não apenas pelo conteúdo que ele lhe ensina, mas fundamentalmente ama o professor pelo fato de ele ser a pessoa virtuosa que ele $\mathrm{e}^{25}$.

$\mathrm{Na}$ q.28, que trata sobre os efeitos do amor, Tomás de Aquino explica, em ad 2, que há uma união que é causa, outra que é essência e outra que é efeito do amor. A união que é causa diz respeito à unidade ou à similitude ontológica entre amante e amado, e Aquino distingue a unidade substancial - que é causa do amor de si - da união por similitude ontológica - a qual é causa do amor de outrem -, afirmando que a unidade é, por assim dizer, mais una do que a união, o que faz com que naturalmente amemos mais a nós mesmos do que a outrem ${ }^{26}$. Mas o amor pelo outro pode ser baseado, como vimos, em uma similitude ontológica

\footnotetext{
${ }^{25}$ É importante assinalarmos que, embora a amizade genuína se funde na similitude atual e persiga um certo ideal de autarquia individual, ela não exclui a existência das diferenças contidas na similitude potencial, a qual possibilita uma série de trocas entre os amigos, uma vez que nenhum humano pode ser inteiramente autossuficiente.

${ }^{26}$ ST, I, q.60, a.3, ad2: "... deve-se dizer que como é mais ser um do que estar unido, também há mais unidade no amor a si mesmo do que no amor a diversas coisas que lhes são unidas (... sicut plus est esse unum quam uniri, ita amor magis est unus ad seipsum, quam ad diversa quae ei uniuntur)".
} 
entre amado e amante que esteja ou em ato ou em potência. Essa dupla similitude serve de base ontológica para uma dupla apreensão da união entre amado e amante, causando uma dupla forma de união afetiva entre amado e amante no interior do apetite do amante. A união afetiva no interior do apetite do amante não é causa eficiente ou final do amor, mas constitui a essência mesma do amor, sendo como que a sua causa formal, mas, como dissemos, ela depende da apreensão que o amante tem de uma certa unidade entre o amante e amado, a qual pode estar ordenada a servir o interesse do amante ou para servir ao amado como serviria a si mesmo. Nas palavras de Tomás de Aquino no corpo do artigo:

(...) quando alguém ama algo com amor de concupiscência, o apreende como pertencente ao seu bem-estar. Do mesmo modo, quem ama alguém com amor de amizade quer o bem para ele assim como o quer para si mesmo, e por isso o apreende como um outro eu, i.e., enquanto quer o bem para ele como para si mesmo. Por isso se diz que o amigo é um outro eu ${ }^{27}$.

Contudo, como a união afetiva não é em si mesma o termo do amor, ela é, por sua condição mesma, imperfeita e, inclinando o amante à busca da união real, causa, no apetite, o desejo por tal união, i.e., pela concretização da união afetiva em união real, pois, somente na união real, que é o termo do amor, o apetite encontra o seu repouso e desfruta da alegria do amor realizado. Ao tratar do êxtase, i.e., do ato de sair para fora de si, como efeito do amor, na ST, Ia-IIae, q.28, a.3, Tomás de Aquino distingue entre o êxtase cognitivo e o êxtase apetitivo ${ }^{28}$. O êxtase cognitivo é caracterizado como consistindo no efeito de pôr o homem para fora da razão natural, o que pode ocorrer de dois modos, a saber, pondo o cognoscente acima ou abaixo da razão que lhe é natural. No primeiro caso, o homem é elevado acima dos limites da razão natural, pela graça divina, chegando a apreender algo que não lhe é conatural como os anjos ou Deus; no segundo caso, ele pode, e.g., perder a sua razão ao ser tomado de assalto por paixões próprias do apetite sensitivo. No que diz respeito ao êxtase cognitivo, Tomás de Aquino afirma

\footnotetext{
${ }_{27}$ ST, la-llae, q.28, a.1: "Cum enim aliquis amat aliquid quasi concupiscens illud, apprehendit illud quasi pertinens ad suum bene esse. Similiter cum aliquis amat aliquem amore, vult ei bonum sicut et sibi vult bonum: unde apprehendit eum ut alterum se, inquantum scilicet vult ei bonum sicut et sibi ipse".

${ }^{28}$ Esse artigo concernente ao êxtase do amor evidencia como é deficiente a inclusão da teoria do amor de Tomás de Aquino na categoria denominada de "concepção física" em oposição à categoria denominada de "concepção extática", segundo as quais Pierre Rousselot dividiu toda a história das doutrinas medievais do amor. Cf. ROUSSELOT, Pierre. Pour L'histoire du probleme de l'amour au moyen age.
} 
que o amor causa a disposição para a produção de tal efeito, mas que o êxtase apetitivo é causado de modo direto pelo amor, cujo próprio tender em direção a outro é já um certo sair de si. O êxtase apetitivo é um efeito do amor que ocorre diferentemente, segundo ele seja causado pelo amor de amizade ou pelo amor de concupiscência. $\mathrm{O}$ êxtase proporcionado pelo amor de concupiscência é dito ser um êxtase secundum quid, i.e., um êxtase parcial, ou até mesmo um falso êxtase, pois como o amante sai de si apenas para obter o amado como um bem para si, ele não sai verdadeiramente de si. Por outro lado, o êxtase proporcionado pelo amor de amizade é dito ser um êxtase simpliciter e um êxtase genuíno, pois, por meio desse amor, o amante sai de si sem retornar para si, na medida em que o bem querido é ofertado ao amado:

Pois no amor de concupiscência o amante é levado de algum modo para fora de si, a saber, enquanto não contente de gozar o bem que possui, busca a fruição de algo fora de si. Mas porque procura ter este bem exterior para si, não sai absolutamente fora de si, mas tal afeição ao fim termina em si mesmo. No amor de amizade, porém, a afeição do amante sai absolutamente para fora dele, porque ele quer o bem para o amigo e age, cuidando e providenciando, pelo próprio amigo ${ }^{29}$.

Assim, resumindo a dinâmica que percorre esses artigos, podemos identificar um duplo modo com que o amante pode se dirigir, por meio de seu amor, ao amado. Ou, fundado em uma similitude ontológica em potência, o amante apreende o outro como um bem para si que, uma vez obtido, preencherá alguma carência sua, causando a união afetiva do amor de concupiscência, a qual produz um êxtase parcial, ou falso êxtase, do amante no amado. Ou, baseado em uma similitude ontológica em ato, o amante apreende o outro como um igual (como um outro eu), a quem quer o bem como a si mesmo, o que causará a união afetiva do amor de amizade, produzindo um êxtase genuíno do amante no amado.

\section{Amando pessoas enquanto pessoas e amando pessoas como se fossem coisas}

Retomando a questão anteriormente formulada: estaríamos, ou não, diante de duas concepções da divisão do amor no pensamento de Aquino?

\footnotetext{
${ }^{29} \mathrm{ST}$, la-llae, q.28, a.3: "Nam in amore concupiscentiae, quodammodo fertur amans extra seipsum: inquantum scilicet, non contentus gaudere de bono quod habet, quaerit frui aliquo extra se. Sed quia illud extrinsecum bonum quaerit sibi habere, non exit simpliciter extra se, sed talis affectio in fine infra ipsum concluditur. Sed in amore amicitiae, affectus alicuius simpliciter exit extra se: quia vult amico bonum, et operatur, quasi gerens curam et providentiam ipsus, propter ipsum amicum".
} 
Uma concepção em que a divisão seria constitutiva de todo ato de amar uma vez que em todo ato de amar quer-se um bem, com amor de concupiscência, para alguém por quem se tem amor de amizade - e outra concepção que produziria dois tipos de amores radicalmente distintos: um que terminaria sempre em amor de si, no amor de concupiscência, e outro que seria genuíno amor de outrem, no amor de amizade.

Alguns autores, e.g., Michel Laboudette, Theerry-Marie Hamonic, Olivier Guillou, admitiram uma dupla concepção da distinção. Eis como Hamonic caracteriza, com precisão, a concepção da distinção como se referindo a uma dupla composição na estrutura do ato de amar:

(...) nestas duas expressões, amizade e concupiscência qualificam por modo de denominação dois aspectos constitutivos do amor enquanto tal, e não já, notemos bem, duas espécies de amor. Estas palavras designam então duas relações, dois elementos constituintes (que de resto não fazem número) que se encontram em toda forma de amor, do mais interessado ao mais altruísta precisamente porque, como já vimos, o amor consiste sempre em querer o bem (finisqui) a alguém (finis cui) ${ }^{30}$.

Labourdette, em seu Cours de Théologie Morale, fala nitidamente na existência de uma outra concepção da distinção:

Ora a mesma oposição (...) tem uma outra acepção mais comum na língua habitual e evocado também, mas com um outro ponto de vista, por estas duas denominações. E não será mais verdadeiro neste sentido que todo ato de amor inclui os dois, ao contrário, ele será um ou outro ${ }^{31}$.

Eis como Labourdette descreve esta outra concepção:

\footnotetext{
30 HAMONIC, 1992, p. 243: “(...)dans ces deux expressions, amitié et convoitise qualifient par mode de dénomination deux aspects constitutifs de l'amour ent tant que tel, et non pas déjà, notons-le bien, deux espèces d'amour. Ces mots désignent donc deux rapports, deux éléments constituants (qui du reste ne font pas nombre) que l'on trouve en toute forme d'amour du plus intéressé au plus altruiste précisement parce que, comme on l'a vu, l'amour consiste toujours à vouloir du bien (finis qui) à quelqu'un (finis cui)". ${ }^{31}$ LABOURDETTE,1959,disponívelem:http:/biblio.domuni.eu/cours/theologie/esperance/ esperance-12htm\#P215 61702: "Or la même opposition: amour de convoitise e amor d'amitié, a une autre acception, beaucoup plus commune dans le langage habituel et sugérée elle aussi, mais à un autre point de vue, par ces deux dénominations. Et-il ne sera plus vrai en ce sens là que tout acte d'amour inclut les deux; au contraire, il sera l'un ou autre".
} 
Donde nossa distinção vem correntemente a exprimir o que se poderia chamar de egoísmo e altruísmo, dando a estas palavras um sentido unicamente físico, sem apreciação moral. Estes não são mais dois aspectos incluídos em todo ato de amor: sua distinção se prende inteiramente ao sujeito beneficiário, ao finis cui; no primeiro, se quer um bem a si, no segundo, se quer um bem a outro, a um amigo ${ }^{32}$.

Embora essas descrições sejam acuradas e mesmo que se possa falar da existência de uma dupla concepção da distinção no pensamento medieval, julgamos que no pensamento maduro de Tomás de Aquino, tal qual expresso na ST, não encontramos duas concepções distintas da mesma divisão, mas se trata tão somente de uma aplicação da mesma concepção da divisão apresentada em sua fórmula geral na ST, q.26, a.4. A aplicação da distinção - como pudemos observar na ST, Ia-IIae, q.27 e q.28 - ocorre no âmbito restrito da relação afetiva interpessoal a fim de determinar o modo com que uma pessoa é amada por outra pessoa: se amamos alguém com amor de concupiscência, queremos essa pessoa como um bem não por si, mas como um bem para nós, mas, se amamos alguém com amor de amizade, então queremos essa pessoa como um bem por si, querendo o bem para ela por ela mesma. Mas, se repararmos bem, em ambos os casos, cada ato de amor envolve a subordinação do amor de concupiscência ao amor de amizade tal qual expresso na formulação geral extraída da Retórica de Aristóteles: se amamos alguém com amor de amizade, então temos amor de concupiscência pelo bem que queremos para ela, e se amamos alguém com amor de concupiscência, então temos amizade por nós mesmos na medida em que a queremos como um bem para nós, mas se a queremos como um bem para outra pessoa, então temos amor de amizade por essa outra pessoa. Assim, encontramos na ST, não uma dupla concepção da distinção, mas uma fórmula geral da distinção seguida de um uso no qual o foco da sua aplicação estaria restrito à consideração do modo com que uma pessoa é amada por outra pessoa. O que aparentaria ser uma nova concepção da distinção, na verdade tratar-se-ia simplesmente de uma aplicação da divisão com vistas a identificar se alguém está sendo verdadeiramente amado com

32LABOURDETTE,1959,disponivelem:http:/biblio.domuni.eu/cours/theologie/esperance/esperance12htm \#P21561702: "Et par là notre distinction en vient couramment à exprimer l'opposition entre ce qu'on pourrait appeler "égoïsme" et "altruisme", en donnant à ces mots un sens uniquement physique, sans appréciation morale. Ce sont ici, non plus deux aspects inclue en tout acte d'amour, mais deux sortes différentes d'amour: leur distinction se prend entièrement du sujet bénéficaire, de la fin cui; dans le premier, on veut un bien à soi; dans le second, on veut un bien à un autre, à un ami”. 
benevolência genuína pelo amante, ou se está sendo amado parcialmente, com amor de concupiscência, em vista do interesse próprio do amante, caso em que aquilo que o amante verdadeiramente amaria seria a si mesmo.

Como vimos, antes de ter apresentado a dupla divisão do ato de amar na ST, Ia-IIae, q.26, a.4, Tomás de Aquino apresentara, no a.1 da mesma questão, uma tripla divisão do amor segundo a tripla divisão do apetite. Quando comparamos essas duas divisões, a triádica (relativa aos três tipos de apetite) e a diádica (relativa aos dois tenderes que constituem o ato de amar), podemos notar que a triádica resulta em três espécies de amor, enquanto que a diádica, não acrescenta mais duas espécies de amor às outras três, mas é uma divisão estrutural reveladora da constituição do ato de amar. Contudo, julgamos que a divisão em amor de concupiscência e amor de amizade é uma divisão estrutural do ato/paixão própria do amor intelectivo, que é ato primeiro da vontade, embora, em sentido lato, também se diga do amor que é ato/paixão dos outros apetites. Segundo a formulação geral da divisão diádica, entendida em sentido próprio, i.e., restrita ao apetite intelectivo, todo ato de amar envolve querer o bem propriamente a alguém e não a alguma coisa, pois aquele a quem se quer o bem, em última instância, deverá ser sempre uma pessoa, seja esta pessoa o próprio amante ou outra pessoa. Assim, a divisão se aplica propriamente ao ato do apetite intelectivo e apenas em sentido derivado, por analogia de similitude, ao apetite sensitivo.

Alguns indícios apontam nessa direção, a saber: o fato da fórmula aristotélica, amare est vele alicui bonum, da qual Tomás de Aquino extrai a divisão ser cunhada, na tradução latina, com o termo velle, que designa o ato do apetite intelectivo, e não com appetere, que designaria os diferentes atos de amor do apetite em geral, e o fato do amor de amizade só poder se dirigir propriamente a pessoas, i.e., a seres dotados de intelecto e vontade. Mas julgamos que a principal razão pode ser encontrada na consideração de que a distinção entre amor de amizade e amor de concupiscência supõe o conhecimento de meios e fins, e que o conhecimento perfeito dos meios e dos fins só ocorre no ato voluntário que é próprio dos seres racionais. Tomás de Aquino concede que os bichos tenham um conhecimento de meios e fins, mas que somente os seres racionais têm um conhecimento perfeito dos meios e dos fins, conhecendo os meios enquanto meios e os fins enquanto fins ${ }^{33}$.

Uma vez admitido que a divisão diádica aplica-se propriamente ao apetite intelectivo, podemos encerrar assinalando que esta divisão do amor

${ }^{33}$ Cf. ST, la-llae, q.6, a.2. 
também pode ser vista como uma maneira de analisar quando uma pessoa é amada como pessoa e quando é amada como se fosse uma coisa. Para Tomás de Aquino, uma pessoa ama uma coisa não por ela mesma, mas em vista de uma pessoa, enquanto que uma pessoa pode ser amada não em vista de outra coisa ou de outra pessoa, mas por ela mesma. Assim, desenvolvendo a comparação feita por Tomás de Aquino do amor de concupiscência com o amor que se tem pelo vinho, apresentada no sed contra da ST, q.26, a.4, podemos dizer que amamos o vinho ou pelo prazer que ele nos causa, caso em que amamos a nós mesmos, ou pelo prazer que causará, quando ofertado, a uma outra pessoa a quem amamos. Nesses dois exemplos, o vinho é sempre amado com amor de concupiscência, embora no primeiro caso ame-se a si mesmo com amor de amizade, enquanto que no segundo caso tem-se amor de amizade pela pessoa a quem se oferta o vinho. Mas isso não exclui que o homem possa coisificar pessoas, como na escravidão, amando-as como se fossem coisas, e personalizar coisas, amando-as como se fossem pessoas, no caso do fetichismo ou da idolatria. Por isso, quando a dupla divisão é aplicada às relações humanas, podemos identificar quando uma pessoa é amada como pessoa, i.e., por ela mesma, no amor de amizade, e quando é amada ao modo com que uma coisa é amada, i.e., em vista do próprio amante, no amor de concupiscência. Isso não implica que não seja legítimo amarmos pessoas secundum quid com amor de concupiscência, pois temos carências que elas podem de boa vontade nos suprir, mas implica que se o fundamento último de nossa amizade por alguém não for o de amá-la simpliciter, i.e., amá-la por si e como um bem em si, então não teremos amor de amizade genuíno por essa pessoa e, consequentemente, a amizade estabelecida não será uma genuína amizade segundo a virtude.

\section{Referências}

AGOSTINHO. A. Doutrina Cristã. São Paulo, Paulus, 2011.

\section{. Commentaire du traité de l'âme d'Aristote. Paris : Vrin, 1999.}

ARISTÓTELES. The complete works of Aristotle. Edited by Jonathan Barnes. New Jersey: Princeton University Press, 1995.

. Éthique à Nicomaque, traduit par Jules Tricot. Paris: Vrin, 2007.

. Nicomachean Ethics. Tranlated by W. D. Ross. London: Britannica Great Books, 1952.

. De Anima. São Paulo: Editora 34, 2006.

ARENDT, H. Le concept d'amour chez augustin. Paris: Éditions Payot et Rivages, 1929. 
GUILLOU, O. Les chemins de l'amitié: désirer et aimer selon Saint Thomas d'Aquin. Paris : Pierre TÉQUI éditeur, 2009.

HAMONIC, T.-M. "Dieu peut-il être légitimement convoité? Quelques aspects de la théologie de l'amour selon le P. Labourdette". Revue Thomiste, Toulouse, 92, 1992, fasc.1, p. 239-266.

LABOURDETTE, P. M. "Cours de Théologie Morale: l'espérance et la charité". Disponível em: http:/biblio.domuni.eu/cours/theologie/index.html

LAUAND, L. J.; SPROVIERO, M. B. Verdade e Conhecimento. São Paulo: Martins Fontes, 1999.

OSBORNE Jr, T. M. Love of Self and love of god in thirteen - Century Ethics. Indiana: University Notre Dame Press, 2005.

PLATON. Charmide, Lysis. Presentation et traduction par Louis-André Dorion. Paris : Éditions Flammarion, 2004.

ROUSSELOT, P. Pour L'histoire du probleme de l'amour au moyen age.

Disponível em: www.ac-nancy-metz.fr/enseign/philo/textes/Probleme_de_1_amour.pdf. WOLF, U. A Ética a Nicômaco de Aristóteles. 2a edição, São Paulo, Edições Loyola, 2007. 